Bull. Chem. Soc. Ethiop. 2017, 31(1), 107-113.

ISSN 1011-3924

(c) 2017 Chemical Society of Ethiopia and The Authors

Printed in Ethiopia

DOI: http://dx.doi.org/10.4314/bcse.v31i1.9

\title{
ANALYSIS OF THE HUSK AND KERNEL OF THE SEEDS OF MORINGA STENOPETALA
}

\author{
Yadessa Melaku ${ }^{1}$, Norbert Arnold ${ }^{2}$, Juergen Schmidt ${ }^{2}$, Ermias Dagne $^{1^{*}}$ \\ ${ }^{1}$ Department of Chemistry, Addis Ababa University, Addis Ababa, Ethiopia \\ ${ }^{2}$ Department of Bioorganic Chemistry, Leibniz Institute of Plant Biochemistry, Halle (Saale), \\ Germany
}

(Received June 2, 2016; revised May 25, 2017)

\begin{abstract}
The ethanol extract of the kernel of the endemic plant Moringa stenopetala after silica gel column chromatography led to the isolation of 4-( $\alpha$-L-rhamnopyranosyloxy)benzyl glucosinolate (1) and sucrose. The oil obtained by Soxhlet extraction with petrol was trans-esterified with $\mathrm{BF}_{3}-\mathrm{MeOH}$ and analyzed by GC-MS. The results showed the presence of diverse fatty acids namely palmitic $(11 \%)$, palmitoleic $(1.2 \%)$, stearic $(11 \%)$, oleic $(63 \%)$, linoleic $(1.2 \%)$, arachidic $(6 \%)$ and the rare behenic acids $(6 \%)$. The white glossy seed husk which comprises $25 \%$ of the whole seed yielded two compounds namely $4-(\sigma-L$-rhamnosyloxy)benzyl alcohol (2) and allantoin (3). To the best of our knowledge this is the first report of compound $\mathbf{2}$ as a natural product. Allantoin is reported here for the first time from the genus Moringa.
\end{abstract}

KEY WORDS: Moringa, M. stenopetala, 4- $(\alpha$-L-rhamnopyranosyloxy $)$ benzylglucosinolate, $4-(\alpha-\mathrm{L}-$ rhamnosyloxy)benzyl alcohol, Allantoin

\section{INTRODUCTION}

Moringaceae is a unique family of only one genus namely Moringa [1], comprising 14 species found in Asia and Africa. The dominant Asian species, M. Oleifera Lam. is widely distributed in the Indian subcontinent and also recently introduced in different parts of tropical Africa. $M$. stenopetala (Baker f.) Cufod. is endemic to East Africa mainly southern Ethiopia and northern Kenya. This species is known by different local names such as Shiferaw (Amharic), Aleko (Gamo Gofa), Shalkayda (Konso), Haleko (Burji), and Halakwa (Wollayta). Its common descriptive English name is cabbage tree (English),

M. stenopetala is a highly valued plant cultivated in home gardens in southern Ethiopia where the leaves are eaten as vegetables [2] and traditionally used against malaria [3], hypertension, asthma, and diabetes. It is also used to heal stomach-ache and expel retaining placenta in women [4]. Pharmacological reports showed that the leaves of $M$. stenopetala showed anti-leishmanial [5], antispasmodic [4], anti-hyperglycemic [6], antibacterial [7], and blood pressure lowering properties [8]. The major secondary metabolite in the leaves is rutin, 4-(4'-O-acetyl- $\sigma-\mathrm{L}-$ rhamnosyloxy) benzylisothiocyanate, and4-(4'-O-acetyl- $\sigma$-L-rhamnosyloxy) benzadehyde [9] .

Moringa seeds are obtained from the pods of the Moringa tree. The seeds are covered by white fluffy husk which encapsulates the kernel (Figure 1). Removal of the husk by de-hulling yields the soft edible kernel, which when pressed yields oil. The seed cake, which is a byproduct obtained after pressing, is used for water treatment [10]. 4-( $\alpha$-L-rhamnopyranosyloxy) benzylglucosinolate (1) was reported before from the seeds [3]. Two compounds from the husk and one additional compound from the kernel are reported here.

*Corresponding author. E-mail: edagne@gmail.com 

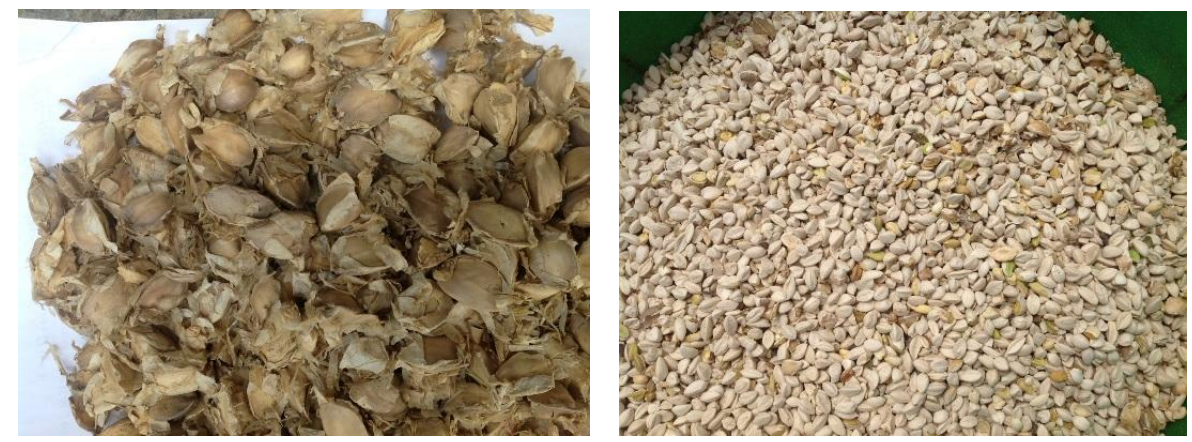

Figure 1. Picture of Moringa seed before and after removal of husk.

\section{EXPERIMENTAL}

\section{Plant material}

Seeds of M. stenopetala were collected from Arba Minch. The plant was identified by Mr. Melaku Wondafrash; voucher specimen (YM002/2015) deposited at the National Herbarium of Addis Ababa University, Ethiopia.

\section{Chemicals and instruments}

All solvents used were analytical grade. Melting points were determined in Digital Melting Point Apparatus. Analytical TLC was run on a $0.25 \mathrm{~mm}$ thick layer of silica gel $\mathrm{GF}_{254}$ (Merck) on aluminum plate. Spots were detected by observation under UV light $(254 \mathrm{~nm})$ followed by spraying with vanillin in $\mathrm{H}_{2} \mathrm{SO}_{4}$. Column chromatography was performed using silica gel (230400 mesh) Merck. Solvent was freed using Rotavapor BÜCHI, RE 121. NMR spectra were measured on Bruker Avance 400 NMR Spectrometer. UV-Vis spectra were recorded on T60 UV-Visible Spectrophotometer. Optical rotations were measured using Autopol ${ }^{\circledR}$ IV Automatic Polarimeter. The IR spectra of compounds were recorded using a Perkin-Elmer BX Spectrometer $\left(400-4000 \mathrm{~cm}^{-1}\right)$ as $\mathrm{KBr}$ pellets.

GC-MS analysis were performed using Agilent Technologies 7820A gas chromatograph system equipped with HP-5 capillary column ( $30 \mathrm{~m}$ x $0.25 \mathrm{~m}$; coating thickness, $0.25 \mu \mathrm{m})$ and Agilent technologies 5977 E mass spectroscopy ion trap detector. Analytical conditions were as follows: Injector and transfer line temperature are 220 and $260{ }^{\circ} \mathrm{C}$, respectively; oven temperature programmed from $60{ }^{\circ} \mathrm{C}$ to $240{ }^{\circ} \mathrm{C}$ at $3{ }^{\circ} \mathrm{C} / \mathrm{min}$; carrier gas, helium at $1 \mathrm{~mL} / \mathrm{min}$; injection $5 \mu \mathrm{L}$; split ratio, 1:30. Identification of the constituents was based on search through mass hunterllibrarylNIST11.L and mass ไhunterllibrarylW9N11.L.

\section{$F T-M S$}

The high resolution positive and negative ion electrospray mass spectra were obtained from a Bruker Apex III Fourier transform ion cyclotron resonance mass equipped with an Infinity ${ }^{\mathrm{TM}}$ cell, a 7.0 Tesla superconducting magnet, an RF-only hexapole ion guide and an external electrospray ion source. Nitrogen was used as drying gas at $150{ }^{\circ} \mathrm{C}$. The sample solutions were introduced continuously via a syringe pump with a flow rate of $120 \mu \mathrm{L} \mathrm{h}^{-1}$. All data were 
acquired with $512 \mathrm{k}$ data points and zero filled to $2048 \mathrm{k}$ by averaging 32 scans. The data were evaluated by the Bruker XMASS 7.0.8 software.

Extraction and isolation of kernel of M. stenopetala

Ground M. stenopetala kernel ( $230 \mathrm{~g})$ were Soxhlet extracted with petrol ether $(2.3 \mathrm{~L})$ for $15 \mathrm{~h}$, filtered and concentrated to afford $36 \%$ yellowish oil. The marc $(100 \mathrm{~g})$ was extracted with EtOH $(500 \mathrm{~mL})$ by shaking for $5 \mathrm{~h}$ with a mechanical shaker, filtered and concentrated to afford $3 \mathrm{~g}(3 \%)$ jelly solid. This was adsorbed and chromatographed over silica gel (230-400 mesh). Gradient elution was done using $\mathrm{CHCl}_{3}: \mathrm{MeOH}$ to afford five fractions $(4: 1,20 \mathrm{~mL}, 100 \mathrm{mg}$ Fr1; 3:2, $30 \mathrm{~mL}, 80 \mathrm{mg}$, Fr2; 1:1, $30 \mathrm{~mL}, 50 \mathrm{mg}$, Fr3; 2:3, $40 \mathrm{~mL}, 98 \mathrm{mg}$, Fr4; 2:3, $40 \mathrm{~mL}, 300$ $\mathrm{mg}$, Fr 5). The fifth fraction was identified to be sucrose $(300 \mathrm{mg})$. Fraction 4 (98 $\mathrm{mg})$ was applied to size exclusion chromatography usingSephadex $\mathrm{LH} 20$ and eluted with $\mathrm{CHCl}_{3}: \mathrm{MeOH}$ (1:1) to afford two fractions (each $15 \mathrm{~mL}$ ). The first and second fractions were identified as 4( $\alpha$-L-rhamnopyranosyloxy) benzyl glucosinolate $(1,40 \mathrm{mg}$ ) and sucrose $(40 \mathrm{mg})$, respectively.

\section{Preparation of fatty acid methyl esters (FAME)}

M. stenopetala oil ( $2 \mathrm{~g})$ was placed in $25 \mathrm{~mL}$ round bottom flask which contained $6 \mathrm{~mL}$ hexane to which $\mathrm{BF}_{3}-\mathrm{MeOH}(4 \mathrm{~mL})$ was added. The reaction mixture was refluxed in water bath for 30 min. To the cooled mixture, $5 \mathrm{~mL}$ of water was added with shaking. The upper layer was separated by using separatory funnel, dried over anhydrous sodium sulphate, filtered and concentrated to afford $500 \mathrm{mg}(25 \%)$. A small portion of the methylated fatty acids was dissolved in hexane and analyzed using GC-MS.

\section{Extraction and isolation of compounds from the husk of M. stenopetala}

The whole seed was separated first into husk (25\%) and kernel. The finely powdered husk (100 g) was extracted with EtOH $(600 \mathrm{~mL})$, using a mechanical shaker $(8 \mathrm{~h})$, filtered and concentrated to afford $2 \mathrm{~g}(2 \%)$ yellowish jelly semisolid. This was adsorbed and applied on silica gel column with solvent system $\mathrm{CH}_{2} \mathrm{Cl}_{2}: \mathrm{MeOH}$ of increasing polarities as eluent to afford 27 fractions (each $40 \mathrm{~mL}$ ). Fraction 8 (eluent $\mathrm{CH}_{2} \mathrm{Cl}_{2}$ ) was identified as stearic acid. Fraction 19 eluted with $\mathrm{CH}_{2} \mathrm{Cl}_{2}: \mathrm{MeOH}$ (4:1) was found to be compound 2 (20 mg) while fraction 24 eluted with $100 \% \mathrm{MeOH}$ was identified as allantoin $(20 \mathrm{mg})$.

4-( $\alpha$-L-rhamnopyranosyloxy)benzylglucosinolate (1)

Yellowish jelly solid; TLC $\left(\mathrm{R}_{\mathrm{f}}\right.$ 0.5, mobile phase EtOAc:MeOH 3:2); UV $\lambda_{\max }(\mathrm{MeOH}) \mathrm{nm}$ : 245, 273; FT-MS: molecular formula $\mathrm{C}_{20} \mathrm{H}_{28} \mathrm{NO}_{14} \mathrm{~S}_{2}^{-}, \mathrm{m} / \mathrm{z} 570.0960$ (calcd 570.5666 for $\left.\mathrm{C}_{20} \mathrm{H}_{28} \mathrm{NO}_{14} \mathrm{~S}_{2}{ }^{-}\right)$; IR $v_{\max } \mathrm{cm}^{-1}: 3400$ (OH stretching), 2924 (C-H stretching), and $1613(\mathrm{C}=\mathrm{C}$ stretching); ${ }^{1} \mathrm{H}-\mathrm{NMR}\left(400 \mathrm{MHz}, \mathrm{D}_{2} \mathrm{O}\right): \delta_{\mathrm{H}} 7.25(2 \mathrm{H}, d, J=8.40 \mathrm{~Hz}, \mathrm{H}-3,5), 7.04(2 \mathrm{H}, d, J=8.40$ $\mathrm{Hz}, \mathrm{H}-2,6), \delta 5.30(1 \mathrm{H}, d, J=1.36 \mathrm{~Hz}, \mathrm{H}-1$ ' '), $1.13(3 \mathrm{H}, d, J=5.60 \mathrm{~Hz}, \mathrm{H}-6$ ' '), 4.00 (2H, bro. $s, \mathrm{H}-7)$ and $4.00-3.00$ (methine protons of the sugar moieties); ${ }^{13} \mathrm{C}-\mathrm{NMR}\left(100 \mathrm{MHz}, \mathrm{D}_{2} \mathrm{O}\right)$ : $\delta_{\mathrm{C}} 162.5(\mathrm{C}-8), 154.6(\mathrm{C}-1), 129.4$, (C-3, 5), 117.5 (C-2, 6), 98.8 (C-1'’), $81.3(\mathrm{C}-1$ ') 60.2 (C6'), 37.4 (C-7), 16.5 (C-6'), 79.8, 76.6, 72.0, 71.7, 70.0, 69.9, 69.4, 68.7 and 60.2 (C-6').

4-( $\sigma$-L-rhamnosyloxy)benzyl alcohol (2)

White solid; $\mathrm{mp} 153-155^{\circ} \mathrm{C}$; TLC $\left(\mathrm{R}_{\mathrm{f}} 0.6\right.$ mobile phase EtOAc:MeOH, 4:1); $[\alpha]_{589}^{21}=-15(0.4$, $\mathrm{MeOH}$ ); UV $\lambda_{\max }(\mathrm{MeOH}) \mathrm{nm}: 271$; IR $v_{\max } \mathrm{cm}^{-1}: 3387$ (OH stretching), 2920 (C-H stretching), 
1612 (aromatic $\mathrm{C}=\mathrm{C}$ ), and 1064 (C-O stretching); ${ }^{1} \mathrm{H}-\mathrm{NMR}(400 \mathrm{MHz}, \mathrm{DMSO}-\mathrm{d} 6): \delta_{\mathrm{H}} 7.22(2 \mathrm{H}$, $d, J=8.20 \mathrm{~Hz}, \mathrm{H}-3), 6.96(2 \mathrm{H}, d, J=8.20 \mathrm{~Hz}, \mathrm{H}-2), 5.32(1 \mathrm{H}, d, J=1.32 \mathrm{~Hz}, \mathrm{H}-1$ ' $), \delta 4.40(2 \mathrm{H}$, $d, J=4.73 \mathrm{~Hz}, \mathrm{H}-7), 5.18(1 \mathrm{H}, d, J=4.23 \mathrm{~Hz}, \mathrm{OH}), 5.92(1 \mathrm{H}, d, J=5.92 \mathrm{~Hz}, \mathrm{OH})$, and 4.81 $(1 \mathrm{H}, d, J=5.92 \mathrm{~Hz}, \mathrm{OH}), 3.25\left(1 \mathrm{H}, m, \mathrm{H}-5^{\prime}\right), 3.43\left(1 \mathrm{H}, m, \mathrm{H}-3^{\prime}\right), 3.61\left(1 \mathrm{H}, m, \mathrm{H}-2^{\prime}\right)$ and 3.62 $\left(1 \mathrm{H}, m, \mathrm{H}-4^{\prime}\right), \delta 1.07\left(3 \mathrm{H}, d, J=6.14 \mathrm{~Hz}, \mathrm{H}-6\right.$ ') ${ }^{13} \mathrm{C}-\mathrm{NMR}(100 \mathrm{MHz}, \mathrm{DMSO}-\mathrm{d} 6): \delta_{\mathrm{C}} 155.3(\mathrm{C}-$ 1), 136.2 (C-4), 128.4 (C-3), 116.6 (C-2), 98.8 (C-1'), $\delta 72.2$ (C-4'), 70.8 (C-2'), 70.6 (C-3'), 69.7 (C-5'), 62.9 (C-7), 18.2 (C-6')

Allantoin (3)

White solid; mp 220-222 ${ }^{\circ} \mathrm{C}$; TLC $\left(\mathrm{R}_{\mathrm{f}} 0.3\right.$ mobile phase EtOAc:MeOH, 4:1); UV $\lambda_{\max }(\mathrm{MeOH})$ nm: 266; FT-MS: molecular formula $\mathrm{C}_{4} \mathrm{H}_{6} \mathrm{O}_{3} \mathrm{~N}_{4}, \mathrm{~m} / z 181.0332$ (calcd 181.10537 for $\mathrm{C}_{4} \mathrm{H}_{6} \mathrm{O}_{3} \mathrm{~N}_{4} \mathrm{Na}$ ); IR $v_{\max } \mathrm{cm}^{-1}: 3438$ ( $\mathrm{NH}$ stretching), and 1715 (amide carbonyl); ${ }^{1} \mathrm{H}-\mathrm{NMR}$ (400 MHz, DMSO-d6): $\delta_{\mathrm{H}} 10.70\left(1 \mathrm{H}, b r . s, \mathrm{H}-1^{\prime}\right), 8.10\left(1 \mathrm{H}, s, \mathrm{H}-2^{\prime}\right), 6.97(1 \mathrm{H}, d, J=8.00 \mathrm{~Hz}), 5.85$ $\left(2 \mathrm{H}, s, \mathrm{H}-4\right.$ ') $5.21(1 \mathrm{H}, d, J=8.00 \mathrm{~Hz}, \mathrm{H}-3) ;{ }^{13} \mathrm{C}-\mathrm{NMR}\left(100 \mathrm{MHz}\right.$, DMSO-d6): $\delta_{\mathrm{C}} 174.0(\mathrm{C}-1)$, $157.9(\mathrm{C}-2), 157.3(\mathrm{C}-4)$ and $62.8(\mathrm{C}-3)$

\section{RESULTS AND DISCUSSION}

The composition of the yellowish oil obtained by Soxhlet extraction of the kernel of $M$. stenopetala with petrol ether (36\%) was determined by gas chromatography-mass spectrometry (GC-MS), after converting the oil to fatty acid methyl esters using $\mathrm{BF}_{3}-\mathrm{MeOH}$. The fatty acids were identified by comparing the spectra of the components with the NIST Database. The GCMS results showed that $M$. stenopetala oil contains a large proportion of double bond-containing fatty acids. The dominant fatty acid is oleic acid (63\%), followed by palmitic (11\%), stearic $(11 \%)$, arachidic $(6 \%)$, behenic $(6 \%)$, palmitoleic $(1.2 \%)$, linoleic $(1.2 \%)$ and myristic acids $(0.2 \%)$. These results are similar to that reported for oil from M. stenopetala growing in Kenya [11]. The oil of the seeds of M. oleifera is known as Ben Oil owing to the presence of 5-6\% of behenic acid [12].

The marc after the above Soxhlet extraction was extracted with hot ethanol and chromatographed over silica gel to afford sucrose $(340 \mathrm{mg}$ ) and compound 1 (40 $\mathrm{mg}$ ) as amorphous solid:broad band at $3400 \mathrm{~cm}^{-1}$ due to hydroxyl stretching, molecular formula $\mathrm{C}_{20} \mathrm{H}_{29} \mathrm{NO}_{14} \mathrm{~S}_{2}$ established from (-)-ESI-FT-MS, which displayed a molecular ion peak at $\mathrm{m} / \mathrm{z}$ at 570.0960 (calcd 570.5666 for $\mathrm{C}_{20} \mathrm{H}_{28} \mathrm{NO}_{14} \mathrm{~S}_{2}{ }^{-}$). The peaks at $\mathrm{m} / z 570$ and 97 are characteristic of 4-( $\alpha$-L-rhamnopyranosyloxy) benzyl glucosinolate [13]. The ${ }^{1} \mathrm{H}-\mathrm{NMR}$ spectrum of compound $\mathbf{1}$ displayed signals at $\delta 7.25(2 \mathrm{H}, d, J=8.40 \mathrm{~Hz})$ and $7.04(2 \mathrm{H}, d, J=8.40 \mathrm{~Hz})$ due to symmetrically placed protons on unsymmetrically para substituted aromatic ring. The anomeric proton signal at $\delta 5.30(1 \mathrm{H}, d, J=1.36 \mathrm{~Hz})$ is characteristic of a rhamnopyranosyl group with $\alpha$ configuration [14]. The presence of a rhamnosyl group was further substantiated by the appearance of terminal methyl signal at $\delta 1.13$. The proton signals observed at $\delta 4.60(1 \mathrm{H}, d, J=$ $3.2 \mathrm{~Hz})$ and $\delta 4.00(2 \mathrm{H}$, bro. $s)$ are due to $\mathrm{H}-1$ ' and $\mathrm{H}-7$, respectively.

The ${ }^{13} \mathrm{C}$-NMR spectrum along with DEPT-135 displayed signals due to three quaternary carbons at $\delta 162.5(\mathrm{C}-8), 154.6(\mathrm{C}-1)$ and $130.6(\mathrm{C}-4)$; four methine carbon signals at $\delta 129.4$ $(\mathrm{C}-3,5), 117.5(\mathrm{C}-2,6), 98.8\left(\mathrm{C}-1^{\prime \prime}\right)$ and 81.3 (C-1'); two methylene carbon signals at $\delta 37.4$ (C-7) and 60.2 (C-6'); and one methyl resonance at $\delta 16.5$ (C-6'). The remaining 8 carbon resonances observed in the region between $\delta 80.0$ to 68.0 are attributed to methine carbon signals of the sugar moieties. The connectivity between C-7 and C-8 was evident from the observed HMBC correlation between the carbon signal at $\delta 162.6$ (C-8) with the methylene proton signal at $\delta 4.00$ (H-7). Another key Heteronuclear Multiple Bond Correlation (HMBC) observed was between the H-1" 'signals and the quaternary carbon signal at $\delta 154.6$ (C-1) which established the location of the rhamnopyranose group on $\mathrm{C}-1$. On the basis of the above physical 
and spectral evidence, compound $\mathbf{1}$ was identified as 4-( $\alpha$-L-rhamnopyranosyloxy) benzylglucosinolate (1) (Figure 2).
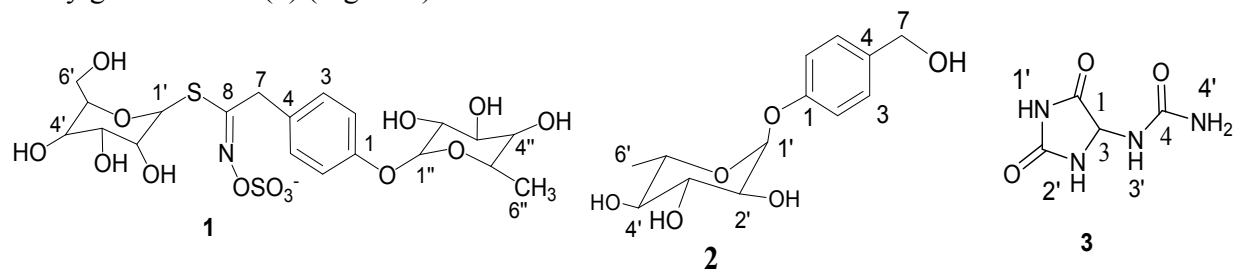

Figure 2. Constituents of M. stenopetala kernel (1) and husk (2 and $\mathbf{3})$.

Sucrose was isolated as a white solid and identified using NMR $\left({ }^{1} \mathrm{H}\right.$ and $\left.{ }^{13} \mathrm{C}\right)$, and FTMS.Further confirmation was doneusing TLC and polarimetry against reference sucrose. Sucrose, which is reported here for the first time from M. stenopetala, accounts for the slight sweet taste of the seeds when chewed.

The ethanol extract of the husk of M. stenopetala was subjected to silica gel column chromatography which led to the isolation of two compounds $\mathbf{2}$ and $\mathbf{3}$ (Figure 2). Compound $\mathbf{2}$ was obtained as a white solid, mp $153-155{ }^{\circ} \mathrm{C}$. It is optically active with $[\alpha]_{589}^{21}=-15$ (c 0.4 , $\mathrm{MeOH})$. The UV-Vis spectrum $(\mathrm{MeOH})$ of 2 displayed absorption maxima at $271 \mathrm{~nm}$ due to $\pi \rightarrow \pi^{*}$ transition. The IR spectrum showed absorption band at $3387 \mathrm{~cm}^{-1}$ due to the presence of hydroxyl group. The proton NMR spectrum of 2 displayed signals at $\delta 7.22(2 \mathrm{H}, d, J=8.20 \mathrm{~Hz}$, $\mathrm{H}-3)$ and $\delta 6.96(2 \mathrm{H}, d, J=8.20 \mathrm{~Hz}, \mathrm{H}-2)$ due to symmetrically placed protons on unsymmetrically para substituted aromatic ring. The ${ }^{1} \mathrm{H}-\mathrm{NMR}$ spectrum indicated the presence of one sugar unit. The anomeric proton signal at $\delta 5.32\left(1 \mathrm{H}, d, J=1.32 \mathrm{~Hz}, \mathrm{H}-1^{\prime}\right)$ and the secondary methyl group resonance at $\delta 1.07(3 \mathrm{H}, d, J=6.14 \mathrm{~Hz}, \mathrm{H}-6$ ') suggest the sugar moiety to be a rhamnose unit. The coupling constant $(J=1.32 \mathrm{~Hz})$ established rhamnose with $\alpha$ configuration [14]. The two hydrogen doublet at $\delta 4.40(2 \mathrm{H}, d, J=4.73 \mathrm{~Hz}, \mathrm{H}-7)$ is due to benzylic methylene protons on oxygenated carbon. The signals at $\delta 5.18(1 \mathrm{H}, d, J=4.23 \mathrm{~Hz})$, $5.92(1 \mathrm{H}, d, J=5.92 \mathrm{~Hz})$, and $4.81(1 \mathrm{H}, d, J=5.92 \mathrm{~Hz})$ are attributed to protons on hydroxyl groups of sugar moiety as established by its HSQC spectrum. The series of signals at $\delta 3.25$ $\left(1 \mathrm{H}, m, \mathrm{H}-5\right.$ '), $3.43\left(1 \mathrm{H}, m, \mathrm{H}-3^{\prime}\right), 3.61(1 \mathrm{H}, m, \mathrm{H}-2$ ') and $3.62(1 \mathrm{H}, m, \mathrm{H}-4$ ') are due to methine protons of the rhamnose moiety.

The proton decoupled ${ }^{13} \mathrm{C}$-NMR spectrum with the aid of DEPT 135 of compound 2 showed the presence of two quaternary, eight methine, one methylene and one methyl carbon signals. The quaternary carbons resonating at $\delta 155.3$ and 136.2 are due to $\mathrm{C}-1$ and $\mathrm{C}-4$ of the aromatic ring, respectively. The other two signals in the aromatic region at $\delta 128.4$ and 116.6 are due to $\mathrm{C}-3,5$ and $\mathrm{C}-2,6$, respectively. The spectrum further disclosed that the sugar unit is a rhamnopyranosyl moiety from the set of the chemical shifts at $\delta 98.8$ (C-1'), 70.8 (C-2'), 70.6 (C-3'), 72.2 (C-4'), 69.7 (C-5') and 18.3 (C-6') in agreement with the proton NMR spectrum. The benzylic methylene carbon signal was observed at $\delta 62.9$ (C-7).

The heteronuclear multiple bond correlation (HMBC) spectrum showed correlation between methylene proton at $\delta 4.40$ (H-7) with the carbon at 128.4 (C-3) and 136.2 (C-4) establishing the site of attachment of C-7 to C-4 of the benzene ring. Another key correlation observed was between anomeric proton signal at $\delta 5.32\left(\mathrm{H}_{-1}{ }^{\prime}\right)$ with the oxygenated aromatic carbon signal at $\delta$ $155.2(\mathrm{C}-1)$ which established the site of attachment of rhamnose to the aromatic ring. This was in agreement with the UV-Vis spectral analysis which showed the absence of phenolic hydroxyl as no bathochromic shift was observed on addition of sodium hydroxide to the cuvette containing methanolic solution of compound 2. Compound 2 was identified as $4-(\alpha-\mathrm{L}-$ rhamnopyranosyloxy) benzyl alcohol, a compound that has not been reported before. 
Compound 3 was identified as allantoin, white solid, mp $220-222{ }^{\circ} \mathrm{C}$. The asymmetric and symmetric stretching of primary amide were observed in the IR spectrum at 3438 and 3343 $\mathrm{cm}^{-1}$, respectively. This was substantiated by the appearance of C-N stretching of primary amide at $1385 \mathrm{~cm}^{-1}$. The intense band at $1715 \mathrm{~cm}^{-1}$ is characteristic of five membered cyclic lactams. The FT-MS showed molecular ion at $m / z 181.0332$ (calcd 181.10537 for $\mathrm{C}_{4} \mathrm{H}_{6} \mathrm{O}_{3} \mathrm{~N}_{4} \mathrm{Na}$ ) compatible with the molecular composition of $\mathrm{C}_{4} \mathrm{H}_{6} \mathrm{O}_{3} \mathrm{~N}_{4}$

The ${ }^{1} \mathrm{H}-\mathrm{NMR}$ spectrum of compound $\mathbf{3}$, identified as allantoin, displayed signals at $\delta 5.21$ $(1 \mathrm{H}, d, J=8.00 \mathrm{~Hz}, \mathrm{H}-3)$ and $6.97\left(1 \mathrm{H}, d, J=8.00 \mathrm{~Hz}, \mathrm{H}-3^{\prime}\right)$. The latter is due to a proton on heteroatom as observed from the absence correlation to a carbon signal in its HSQC spectrum. Other signals in the proton NMR spectrum were at $\delta 10.70\left(1 \mathrm{H}, s, \mathrm{H}-1^{\prime}\right), 8.10\left(1 \mathrm{H}, s, \mathrm{H}-2^{\prime}\right)$ and $5.85\left(2 \mathrm{H}, s, \mathrm{H}^{-} 4^{\prime}\right)$. The downfield signal at $\delta 10.70$ is due to $\mathrm{H}-1^{\prime}$. The singlet signal integrating for two protons at $\delta 5.85$ is assigned to $\mathrm{H}-4$ '. The proton decoupled ${ }^{13} \mathrm{C}$-NMR with the aid of DEPT-135 spectrum of compound 3 showed the presence of well resolved resonances of four carbon atoms, three of which turned out to be quaternary $(\delta 174.0(\mathrm{C}-1), 157.9(\mathrm{C}-2)$ and 157.3 $(\mathrm{C}-4))$ and one was a methine carbon signal $(\delta 62.8(\mathrm{C}-3))$. Compound 3is known to possess anti-inflammatory, anti-asthmatic and wound healing properties $[15,16]$.

In conclusion, the ethanol extract of the kernel of $M$. Stenopetala gave two compounds namely 4-( $\alpha$-L-rhamnopyranosyloxy)benzylglucosinolate (1) and sucrose. The kernel was also found to be rich in fixed oil $(36 \%)$ with diverse fatty acids including myristic $(0.2 \%)$, palmitic $(11 \%)$, palmitoleic $(1.2 \%)$, stearic $(11 \%)$, oleic $(63 \%)$, linoleic $(1.2 \%)$, arachidic $(6 \%)$, and behenic acid $(6 \%)$. Furthermore from the husk 4-( $\sigma$-L-rhamnosyloxy)benzyl alcohol (2)andallantoin (3) were isolated. To the best of our knowledgecompound 2 has not been reported before as a natural product.

\section{ACKNOWLEDGMENTS}

The International Science Program (ISP), Sweden is thanked for research grant.

\section{REFERENCES}

1. Arora, D.S.; Onsare, J.G.; Kaur, H. Bioprospecting of Moringa (Moringaceae): Microbiological perspective. J. Pharmacogn. Phytochem. 2013, 1, 193-216.

2. Padayachee, B.; Baijnath, H. An overview of the medicinal importance of Moringaceae. $J$. Med. Plants Res. 2012, 6, 5831-5839.

3. Mekonnen, Y.; Dräger, B. Glucosinolate in Moringa stenopetala. Planta Med. 2003, 69, 380-382.

4. Mekonnen, Y. Effects of ethanol extract of Moringa stenopetala leaves on guinea-pig and mouse smooth muscle. Phytother. Res. 1999, 13, 442-444.

5. Bekele, B.; Adane, L.; Tariku, Y.; Hailu, A. Evaluation of antileishmanial activities of triglycerides isolated from roots of Moringa stenopetala. Med. Chem. Res. 2013, 22, 45924599.

6. Jaiswal, D.; Rai, P.K.; Kumar, A.; Mehta, S.; Watal, G. Effect of Moringa oleifera Lam. leaves aqueous extract therapy on hyperglycemic rats. J. Ethnopharmacol. 2009, 123, 392 396.

7. Walter, A.; Samuel, W.; Peter, A.; Joseph, O. Antibacterial activity of Moringa oleifera and Moringa stenopetala methanol and n-hexane seed extracts on bacteria implicated in water borne diseases. Afr. J. Microbiol. Res. 2011, 5, 153-157.

8. Mengistu, M.; Abebe, Y.; Mekonnen, Y.; Tolessa, T. In vivo and in vitro hypotensive effect of aqueous extract of Moringa stenopetala. Afr. Health Sci. 2012, 12, 545-562. 
9. Mekonen, A.; Gebreyesus, T. Chemical investigation of the leaves of Moringa stenopetala. Bull. Chem. Soc. Ethiop. 2000, 14, 51-55.

10. Yang, R.; Chang, L.; Hsu, J.; Weng, B.B.C.; Palada, M.C.; Chadha, M.L.; Levasseur, V. Moringa and Other Highly Nutritious Plant Resources: Strategies, Standards and Markets for a Better Impact on Nutrition in Africa. Accra, Ghana; 2006; pp 1-9.

11. Lalas, S.; Tsakni, J.; Sflamos, K. Characterization of Moringa stenopetala seed variety "Marigat" from Island Kokowa. Eur. J. Lipid Sci. Technol. 2003, 105, 23-33.

12. Anwar, F.; Rashid, U. Physicochemical characteristics of Moringa oleifera seeds and seed oil from a wild province of Pakistan. Pak. J. Bot. 2007, 39, 1443-1453.

13. Bennett, R.N.; Mellon, F.A.; Foid, N.; Pratt, J.H.; Dupont, M.S.; Perkins, L.; Kroon, P.A. Profiling glucosinolates and phenolics in vegetative and reproductive tissues of the multipurpose trees Moringa oleifera L. (horseradish tree) and Moringa stenopetala L. J. Agric. Food Chem. 2003, 51, 3546-3553.

14. Kashiwada, Y.; Ahmed, F.A.; Kurimoto, S.; Kim, S.; Shibata, H.; Fujioka, T.; Takaishi, Y. New $\alpha$-glucosides of caffeoylquinic acid from the leaves of Moringa oleifera Lam. J. Nat. Med. 2012, 66, 217-221

15. Barbakadze, V.; Mulkijanyan, K.; Gogilashvili, L.; Amiranashvili, L.; Merlani, M., Novikova, Z.; Sulakvelidze, M.Allantoin- and pyrrolizidine alkaloids-free wound healing compositions from Symphytum asperum. Bull. Georgian National Acad. Sci. 2009, 3, 159165.

16. Lee, M.; Lee,N.; Jung, D.; Lee, J.; Seo, C.; Lee, H.; Kim, J.; Shin, H. Protective effects of allantoin against ovalbumin (OVA)-induced lung inflammation in a murine model of asthma. Int. Immunopharmacol. 2010, 10, 474-480. 